\title{
THE TRUE RELATION
}

\section{OF THE LAST GREAT BATTAILE OF NORLING BETWEENE THE KING OF HUNGARY AND}

\section{THE VNITED PRINCES OF GERMANY.}

Duke Bernard alias Weymar and Gustavus Horne having as I may say little better then fled from the Kings Army which prosecuted them even unto this Cittie of Norling, and finding the neare approach of the Kings Army and his forces not sufficient to withstand the Kings Army alone came and touched at Norling and told them what they were like to trust to, which was a Siege for the King and the Duke were at hand, left them some forces to hold out the longer and refreshed his Army bidding them bee of good heart and hold out, and hee would but goe to encrease his strength and

f. 48. would not faile but relieve them and to bee able to fight with the Ennemy if not to remove hym from the siege, and so away hee went into the Land of Wertinburg, where having got more forces made no long stay but to Norling hee comes backe againe, where he finds the Ennemie but newly and rawly entrenched not expecting Weymars so suddaine returne. But Weymar came bravely on with his Army and past vs. as though hee would presently fight with us. His horse and ours encounters and while wee were busy thus on our right-hand file hee sends three Troopes of his horse upon his left-hand file and behind every horseman a Musquetier, and approached up to a Mill which lyes close to the Walles of the Towne and caused there Musquetiers to alight, whome the Towne were ready prepared to receave and bring them in: and wee not conceiting such a Stratageme that they had Musquetiers behind them, but that onely they were come to make a bravado: and with all wee had enough to doe with the Ennemy on the left-hand file, wee could not have well come tyme enough to hinder them.

But Duke Weymar having donne that which hee came for viz to relieve them and night growing on, on the suddaine retreated and in an Instant to a great ${ }^{-1}$ Hill which lay about the space of an English Mile from our Leaguer, whereon stood a Castle and at the foot of the Hill a little stronge Towne and a deep Moate about it, in which Towne lay 3000 Musquetiers : and his whole Army lying upon the Hill, having provision enough by reason all the Country

1 The Arnsberg. The little strong Town is probably Elderheim. 
behinde them was theirs as namely the Land of Wertingburg, Swaven, Franconia, and the Palatinate and so up to the Borders of Swisherland: and there hee lying some 8 or 10 dayes wee daily f. $48 \mathrm{~b}$. expected Battaile : in that tyme came the Cardinall Infant with his Army out of Spaine to goe into the Low Countryes, and lay at Donwart some three German Miles of, which the King of Hungary had lately taken in, whereof when the King heard, sent to hym to congratulate his comming and to know withall whether it pleased hym to bee with his Army at the Battaile which hee daily expected, and to ioyne with hym, which hee very willinglie did and the next day wee drew our Army out of their Trenches, horse $\&$ foot with all our Canons, and gave three Volleys of shot Canons and Musket all ouer the Armie for the honour of the Cardinalls comming.

Duke Weymar hearing this and knowing the cause, was much angrie and swore hee would send the proud Spaniard backe to Spaine with a pestilence. But the next day broke up his Army from the Hill and wheeled about a Wood which was nere, as if hee would march into Wertingburg-Land: wee sending out our Skouts after hym, they returning said that certainely hee was marched backe againe, that which dazeled and blinded their discovery because hee kept his Reregard so farre behinde. This newes beeing brought to the Camp our Generalls gave leave to most part of our horse to goe to their Quarters to refresh themselves having stood in Battaglia a whole night and a day. But Coronell Butler (whose name I can not mention without reverence) having the Guard half an English Mile before the Army sent mee and Cap $^{\mathrm{n}}$ Burke up to a Rocke to discry if wee could which way the Ennemy had taken his march : and wee two riding upon the top of the Rocke all alone, saw the Ennemies Rere-gard marching toward the left hand : wee tooke our way downe the Rocke into a Wood at the foot of the Hill and in the Wood wee found a f. 49. Tracke where a Troop of horse had marched before vs wee supposing it was a Troop of the Ennemies horse followed them, and going thus a space of a quarter of an hower seeing no bodie, we heard Drummes \& Trumpets sound not knowing whether it were frend or Ennemy comming to the end of the Wood, wee saw the whole Army of the Ennemy in a great field behind the Wood standing in Battaglia with their front towards our Army: wee seeing this beeing both well mounted in hast tooke our retreat backe to our Regiment and acquainted our Coronell with what wee had seene, who presently sent us in post to the King to acquaint hym with it; who would not believe it, but wee had no sooner 
spoken the Word but there came a Courier who told the King that the Ennemies was fallen upon our gard $w^{\text {ch }}$ Count Butler did comaund. But our Sergeant Maior Generall Count Marachin, having the Gard behind hym with 3000 horse seconded Count Butler : but the Ennemie approached with great force, and our Generalls Person, having not notice tyme enough before wee could get ${ }^{1}$ the Infantery to ayde vs the Ennemy had put vs to small retreat : and in the skirmish was slayne Baron de Turnet' Coronell de Binder and Coronell Nicolà was sore wounded, Coronell Devreux was shot in the right thigh : where this skirmish was made upon our left hand stood a $\mathrm{Hill}$ which the Ennemy was desirous to get : where wee had a Spanish Capitaine with 200 Musquetiers. Our Generall seeing the Ennemy did strive to assault the Hill sent mee with 200 Dragoniers to ayde the Spaniard there. But the night grew on and the Ennemy had approached with in half a Canon-shot of the Army, and our Generall thinking wee were too weake to maintayne that Hill sent a Lieutenant Coronell with 500 Spanish Musquetiers to relieve mee, and I

f. $49 \mathrm{~b}$. to returne but I could not passe but I must come thorough the Ennemies garde, which lay betwixt mee and my Regiment, but I was resolute to passe through them with my Dragoniers and beeing darke commaunded none should discharge till they were bidden, and so marched close togeather, they calling often for the Word, but I gave no answeare, till we were in the midst of them and then on a suddaine wee discharged all togeather that made a great confusion among them, whether they thought till then wee were frends that they did not shoot, but then they bestirred themselves. My Coronell lying not far from thence, hearing this doing came up with his Regiment and brought mee of for there hee lay expecting my coming.

The Ennemie hearing this Alarme thought that the Spaniards which kept the Hill were fallen upon their Gard : approached up to the Hill \& assaulted it : but the Spaniards beate them backe. The Sweves tooke courage and set on it againe and this Assault did last for three howers, at last they tooke in the ${ }^{3}$ Hill \& cut of most of the Spaniards: some of the principall officers they gave Quarter vnto: but the next morning brought those Spaniards before the whole Army and shot them to death contrary to the

1 There is some confusion in language here.

* These officers, if their names are correctly given, do not appear to be mentioned elsewhere except 'de Turnet,' who is 'Baron de la Tornetta.' Khevenhüller. XII, I2I3.

${ }^{3}$ The Häselberg. (Wille, Hanau im dreissigjahrigen Kriege, p. I32.) or possibly the "Allbuch." 
Lawe of Armes. This Hill beeing taken in, they brought their Canons upon it and the next morning by breake of day they began to play with them into our Leaguer which was the speciall thing they aymed at. But our horse and the Spanish horse beeing come (who had marched all night) made a stand and began to draw their Batallia up into divisions, but the Ennemy very resolutely approached and tooke a skonce in of ours, which lay hard under the Hill which they had new gotten of us, and played upon us with Canon of the Hill \& of the Skonce which gauled the Spanish Army ; but the Spaniard approached with his whole Army and tooke in the Skonce \& Hill againe, and put the Ennemy to f. 50. retreate in which Ennemies retreat wee tooke Prisoners Coronell $\mathrm{Hew}^{1}$ a Scottish-man Cap ${ }^{\mathrm{n}}$ Christen and Cap $^{\mathrm{n}}$ Fiscots ${ }^{2}$ and Capn Ramsey a Scot and Coronell Musten was shot dead and many a brave sparke more, during this hot fight the Towne sallyed out on our backes and did us much mischief : but wee beate them often backe.

Duke Weymar seeing the service so hot on the right hand file and like to have the worst of it, fled to Policy, and thought if hee could get out and fall upon the Kings backe who was very attentive to maintayne this fight on the right hand-file, hee should puzzle the King extreamely coming so unlooked for, tooke two strong Troopes of horse and marched towards a passe where I was comaunded to stand with 200 Dragoniers by Picolominie, who had carefully observed \& viewed all passages of danger. Before mee I had a Quick-set hedge and a bog of about a pistol shot in breadth and in the midst a narrow passage of fower in ranke which narrow passage Duke Weymar had found and thither hee comes but not knowing or thinking any body was there yet to prevent danger sent a Troop of 200 horse to see if the passage were cleare, which Troop I embraced with a volly of 50 Musquetiers then 50 more and so kept their order 50 at a tyme and coming so unexpected vpon them made such a confusion among them man \& horse tumbling in the bogs that it grieved my self to see them. Weymar swearing intolerably and the more hee strove to second them with fresh in that heate the more they fell into disorder, I and my Troopes standing in security and at our ease having 50 fresh shot upon them still. At length I could heare hym sweare and call aloud to bring downe 500 horse and

' 'Hew' may be the real name, or it may be an error for 'Hume' or 'Home'. Thomas Hume of Carrolside was Lieut. Col. of the Rhinegrave's regiment of horse.

'. Fiscots' is possibly (a Lindsay of) 'Pitscottie'. 
300 Musquetiers more. I hearing hym say so, sent presently a Courier to Galas our Generall that if hee would have that passe kept, hee must send more forces : John de Wert hearing this came hymself and brought 500 Crabats and 300 Musquetiers : the Crabats beeing come I marched over with my Dragoniers and played upon the Ennemy with them till the Crabats got over with the 300 Musquetiers and beeing got over John de Wert encountred with Duke Weymar but was beaten backe to the bog but John de Wert sending backe for 5 Regiments of Cuirassiers got a good courage and at the second encounter got 5 Colours in the skirmish, with which Duke Bernard was much vexed, that hee called aloud to fetch 3000 Musquetiers more $\&$ the rest of his horse that had a field piece betwixt every Troope. And the bottome wherein they fought was but small and had more horse and men then they could well order there already beeing betwixt two great Hills : but John de Wert having got some advantage held it and followed it with fresh horse upon horse that there was a bloody fight. At length came Duke. Weymars horse but there was no roome for them to employ them to the Dukes relief, but the Dukes forces beeing once in disorder John de Wert plyed hym so hard that hee would not give hym leave to make any stand : and then these new forces coming in the necke of the other that there was such a generall confusion among them that the Dukes Infantry which were in the bottome were all cut downe, and themselves out of order lost their courage and away they fled, and John de Wert followed the Duke in slaughter 6 English Miles : so it seemes a man may have too many men as well as to few, unlesse hee have roome to order them in, as it fell out here : and what a little oceasion as such a bog as this should order all the order of the Battaile and bring the

f. 51. Battaile out of the plaine champion into a little bottome, which was as was thought, they would have got the day in the plaine field, and all that Duke Weymar now [did] was in heate and choler without consideration comming to bee beaten backe at such a passage. But Gustavus Horne although hee saw that Duke Weymar was overthrowne on the right hand and fled, which was enough to discourage a good spirit, yet fought like Dragons two howers after; and on the other side the Spaniards were as much encouraged to see wee had got the day, that they fought like Tygers and so long and having fresh supply that at length Gustavus Horne was taken Prisoner and Sergeant Maior Generall Cratz who as I said before had runne from Ingolstad, and many a brave Cavalliero cut downe. The rest of the Army began to fly and our Infantery with our horse following the slaughter for the space of twenty English Miles. 
There wee got all their Canons and other field-pieces which were above fiftie in number and all their Amunition Wagons and Baggage-Wagons above fower thousand with all their Colours: and withall wee found such a number of Ladies and Commaunders Wives that I can not count them, and all of them taken Prisoners. John de Wert followed the execution after Duke Weymar thorough the Land of Wertinberg with his light horse \& Crabats till hee came to a Towne called Holbrum ${ }^{1}$ which was 50 English Miles and more standing upon the River of Neckar, where Duke Weymar had 5 Companies of souldiers and there made a stand, the Towne was too strong for hym ; and so returned and coming by a Towne called Keeping ${ }^{2}$ where lay Coronell Grinoway ${ }^{3}$ an English man with his Regiment belonging to Duke Weymar, hee seeing the battaile lost, Weymar fled and hymself riche gave up the Towne with his whole Regiment to the service of the King of Hongary.

Then the King marched with his whole Army thorough the Land of Wertinberg to Kirken ${ }^{4}$ vndre, but the Duke who had an Army of his owne Boores of ten thousand threw away their armes and run away and left their Duke shift for hymself who fled to Straseburg but John de Wert followed hym through a Wood called Swartzwald and upon the other side of the Wood meets with the Ringrave with an Army of 8000 not one knowing of the other.

The Ringrave was so amazed first seeing the flight of the Duke of Wertinberg and John de Wert coming so suddainely upon hym in good order after, made a stand and encountred, but the Ringraves horsemen beeing discouraged therewith made a retreat towards the River of Rhene, thinking to swim with his Cavalliery over the Rhene was drowned therein hymself with many of his horsemen who was coming with his Army to the Battaile of Norling.

But the King of Hongary beeing come to Kirkenvndre wherein lay two Companies of Duke Weymars. The Commaunder did yield up the Towne as the former did and the King left Coronell Butler there with certayne Regiments as Comaunder to take in the rest of the Country. Which doune the King marched forwards to the Towne of Holbrum as aforesaid and beleagred it, and tooke it in by force but not without burning half thereof. The King stayed here a long tyme and divided his Armie into three parts : Count Redburg ${ }^{5}$ marched into Franconia and tooke in all the Townes \& Castles thereabouts.

1 Heilbronn.

2 Göppingen.

3 ? Greenway.

4 This seems to be Kirchheim unter (Teck)

${ }^{5}$ Riedberg, (Theatr. Europ: iii, p. 639.) 
Gallas marched with an other Army toward the Rhene and coming nere Heydleburg met with certaine Troopes of the french Armie which did encounter with hym, but the french getting more f. 52. ayde hauing the Towne \& Castle to help, Gallas was forced to retreat. The Duke of Lorayne having the Reregard of the Armie and the french approaching strong upon hym was forced to leave 3 of his Canons behinde hym and so went to Holbrum to the King, and there the Winter Quarters were delt out which fell out to bee so neare the Ennemies Wynter-Quarters that as much harme was donne to both sides with often Incursions as if the Armies had bene in the field. And Coronell Despanias Quarters fell out to bee betwixt Holbrun and Heydleburg which was in the french hands and one Coronell Dubartle ${ }^{1}$ one of Duke Weymars Army, which had bene lately taken Prisoner and had lost most part of his Regiment, and beeing ransomed and getting an other Troope of horse fell into Coronell Despanias Quarters and cut of most of his men and hymself was taken Prisoner, after this manner they spent the whole Wynter.

But I should have told you that as there was great sorrow on Duke Weymar his Syde for his losse, which you must judge was sorrow enough : so on the other side the joy was in extremity, for what expression of joy could bee made there was ether in Drummes Trumpets, Canons \&c. for so great a Victory. Te Deum was presently sung thorough out all the Armie that was left, for those that followed the poursuite had more mynde of taking pray then of making prayer I thinke. Especially the Congratulation of the young King with the young Cardinall, how God had donne them that honour to meet almost by miracle at so great a Victory. Bavaria and Loraine had their shares in this ioy. The Battaile ended the Cardinall prepared for his journy and after leave taken very solemnely by the good Princes: the Cardinall went away by Colen : ${ }^{2}$ and thorough Colen ; whither the Citty it is thought had invited f. 52 b. hym as it seemes by his entertainement for hee was met within a Mile of by the Lords of the Citty : and at his entrance by all the Clergie especially those Electorall Bishops and others that were fled for refuge thither from the face of the Swevish King and by them brought to the High Church thorough all the Streets, hanged and strewed where hee heard a delicate Sermon with Te Deum sung all the way: where hee rested that night. The next day marched

1 Taupadel. He had been captured by Butler at the taking of Schorndorf.

${ }^{2} \mathrm{His}$ army crossed the Rhine not at Cologne, but at Andernach. But he himself went on to Cologne. Theatr. Europ., iii, p. 372. Poyntz's story is quite correct. 
away with all speed: but before his going made the Cittizens a gratulatory speach for their more then kingly entertayment of him : and with all it did rejoyce hym much to see them so firme in the Catholique faith : and what a favour God had donne them to have the happinesse their Towne to bee the Civitas Refugij to the Saints which had fled to them for succour. But amongst all hee had an ey of the Bishop of Wertsburg where the Swevish King had found so much Money: whome hee much blamed that Knowing what distresse the Emp ${ }^{r}$ was in for mony, and thereby the Empire, and yet would suffer so much Mony and gold to ly resting there, that that which was layd up there for the good of the Empire should fall into an Ennemies hands and thereby destroy the Empire by Gods permission. The Bishop [said] it was laid there by his Predecessours to which hee had followed their course and made some addition of his yearly revenew as they did, and indeed durst not without some great offence adventure of stirring it.

Notwithstanding this great Victory, the Towne of Norling from which wee have long digressed was not discouraged but held the King play a long tyme with great losse as well by their often sallies when hee was in fight with Weymar as also now beeing often beaten backe from many assaults : whereat hee beeing angrie made f. 53 . his Cuirassiers to allight who are horse-men armed Cap a pied who were also served in like sort : of which Companie I was one : where was a strife betwixt one and my self for one Ladder, whether of us should goe up first, hee would have the first honour, \& I would have it hee pleaded hee was my ancient in service and so hee was, and I let hym goe, a proper young man hee was and up hee went and I followed hym at heeles so soone as hee came to the Top of the Walles, his head was no sooner peeped up above the Walles, but it seemes one thrust at hym with a Halberd and thrust of his Bever, his Bever was no sooner of but with a sword one strucke of his head and fell to the ground the head beeing of the body falls upon mee and there it lyes very heavy upon mee and blooded mee wonderfully that I was almost smothered with blood. I not knowing what was the cause cryed what the Devil ayld you that you doe not mount higher, but what with the weight and with the blood I could hold no longer and downe wee fell togeather and what with my fall upon the stones and hee in his armour upon mee that I knew not whether I was alive or dead, but after I came to myself sore bruised and bloody I crawled to the Wall and stood close where I saw them run from the Assault, I though overloaden got away the bullets coming flying after us, which chance was much observed afarre of and I had such wondring at mee to see 
mee so bloody all over and yet not wounded. But yet the King would not bee beaten of so but got it at last to the Townes-mens cost who were all slayne.

The Princes of the Vnion were wonderfully dejected with the overthrow of their two Generalls, and with them almost all their forces \& strength presently sent a Post to Prague at the siege f. $53 \mathrm{~b}$. whereof they knew very well the Duke of Saxony lay with Banier to acquaint them in what state they were, and that with all speed hee could that hee would make their peace with the Empr otherwise prosecuting his Victory they would all bee outed of their Countries : hee as I have formerly writ neglected no tyme but made good use for hymself and them of it : and a Peace was concluded and a Dyet to bee held at Ratisbone (lately taken in by the King of Hongary) and so it was the next sommer after.

Now to the King againe : the Sommer coming on Gallas drew into the field (for the King of Hongary wintred most part in Vienna and was not yet come to his Army) and marched to Heydleburg and beleagred the Towne and Castle, the Comaunder thereof was Coronell Huncks ${ }^{2}$ an English man. Gallas lying there about the space of 14 dayes broke up from thence leaving certaine Regiments about it an [sic] marched towards Mannum ${ }^{3}$ and there hee pitched his Leaguer and lying certaine dayes there, broke up againe and left two Regiments of foot with young Papenham ${ }^{4}$ of 6000 men with 3 Companies of Dragoniers lying a mile of onely to keep that no provision should come to the Towne. And Gallas with the rest of his Army marched towards Wormes where lay 3 Regiments of french $\&$ Swevish where Gallas built a Bridge ${ }^{5}$ betweene frankendall \& Wormes and marched over with half his Army, and beleagred the Towne on both sides and laying there the space of 8 dayes tooke in the Towne upon composition laying downe their Armes and Colours and put a Garrison in the Towne: and sent Don Hannibal de Gonzaga with 3 Regiments of horse and foot to frankendall and there to entrench themselves a Mile of to Keep out

f. 54. provision and lay there the space of 24 weekes where were Prisoners taken \& killed on ether side in sallies. But Coronell Smith-

1 Nördlingen surrendered on good terms the day after the battle. The whole story seems misplaced.

2 Abel Moda a Swede was the real commandant, but Huncks was a real person, who fought at Maestricht. Markham, 'Fighting Vercs,' p. 445.

3 Mannheim.

4 Nephew of the cavalry general, and defender of the Wülzburg against Gustavus Adolphus in I63I. cf. Harte, ii, p. 126 note. Pappenheim had but one son, born in 1618 .

s. e. across the Rhine at a point between the two towns. 
burg $^{1}$ Governour of the Towne of Mannum finding his Amunition and provision to grow short, agreed to yield up the Towne laying downe colours \& Armes, and all them that had mynde to serve the Emp ${ }^{r}$ and stay might, and was to bee conveyed with his Companie to Metz in Lorraine, but tarrying long for his conduct betweene frankendall and Mannum came certaine straggling parties from our Army $\&$ fell into his Quarters where hee lay with his baggage and beeing disarmed men, pillaged his baggage and put his men to flight that the Coronell alone took his way with a Page in the night towards Haganaw where lay a Regiment of the french and there hee stayed.

But the Towne of frankendall seeing the Towne of Mannu given up and no hope of relief, began to parly that they might march out with bag and baggage, flying Colours, burning Matches and bullet in mouth but the Regiment which was called the Holland Regiment was to bee conveyed downe the River of Rhine towards Holland and a french Regiment to bee conducted as far as Elses ${ }^{2}$ Chabur which lyes in Alsatia upon the passage vp to Loraine, so the Towne was yielded.

But Gallas hearing the french Armie lay about Mentz marched thither; but the french not thinking themselves strong enough to stay his coming broke up and marched towards Chritznocke. ${ }^{3}$ Gallas beleagred Mentz and sent a flying Army up to Chritznocke to assault the Towne, and tooke half the Towne but the french kept the other half with the Castle, and the french having got a new supply drive out the Imperialists cutting of 2000 and so the rest were constrayned to retire backe to Gallas, who hearing this f. $54 \mathrm{~b}$. news broke up from before Mentz, for that the french with their new supply followed the flying Armie even to Mentz.

Gallas marched backe to Wormes againe there tarrying till the King of Hongary came with an Army of 15000 men which Count Colredor had commaunded in Bohemia when the King came to Holbrun, hee sent the said Colredor with the Armie to Gallas which beeing come joyned togeather and went over the Rhene at Wormes and went to franckford on the Mayne and pitched his Leaguer betwixt franckford and Darmstat. The french Generall built a bridg at Mentz and began to approach to Gallas, but hauing notice hee had a new supply retreated hymself to an Iland which is called Gustavus-burg, ${ }^{4}$ lying betwixt the Rhene and the Mayne; there they

1 Schmidtberg, best known for his defence of Philippsburg after Nördlingen.

${ }^{3}$ Elsass Zabern.

${ }^{3}$ Kreuznach.

${ }^{4}$ Harte, ii, p. II7. Modern historians say little of this matter, but the Theatrum Europacum has a plan of the place, ii, p. 604 . 
lay both Armies facing one the other for the space of 4 Moneths. This place called Gustavus-burg was built by the King of Sweve by his owne name viz. the Cittie of Gustavus : and it was a thing of great importance for it commaunded Mentz and also the River of Rhene that nothing could passe without its leave paying contribution. And the King was so earnest in the edification of it that hee placed all about that they that would come and build and live there should have greater priviledges then other places had, and it almost beggered Mentz and defaced it ; for most of the Churches, Abbeyes and Religious houses were pulled downe for the Stone to bee brought to build Gustavus-burg, and so they did from any Towne round about where they could get any, that before the King was

f. 55. killed it was growne to a great Citty, but since his death it is almost come to nothing ; for the french souldiers getting the commaund there and every where with the Sweve, both goe to wracke one envying the other.

In the meane tyme the King of Hongary lying at Holbrun, brought all the free Townes to Composition with hym and submitted themselves, as namely Norinberg, Wollom, ${ }^{1}$ franckford on the Mayne, but Straseburg would and would not as hee [saw] the successe. But franckford having 2000 Musquetiers lying in one half of the Towne of the Sweves forces, the Comaunder whereof was Coronell Kniphousen ${ }^{2}$ who did not know at first the Lords of franckford were gonne to the King to Holbrum about peace, but at last got notice of it, by this their secrecie hee expected some rough dealing : the Lords suddainely upon their returne without any warning to the Comaunder turned all their Canons upon the Sweves and shot fiercely vpon them and withall sallyed over the Bridge, thinking to beat hym out of his Quarters but hee receaved them with such Vollies of shot that they were constrayned to retreat backe with the losse of many. This continued the space of 8 dayes so that the Lords of the Towne were forced to write to Gallas for ayde, who sent them 8000 men by Marquesse de Grande ${ }^{3}$ who beeing come in short tyme the Governor began to parley and at length it was agreed hee should march away with flying colours, bullet in the Mouth, bag and baggage 5 pieces of Canon and 6 Wagons of Amunition and convoy for hymself to Mentz where the french Army lay. This half Towne thus yielded and hee marching out with all his souldiers, baggage \&c hee thinking to have a convoy for all his 2000 men, our Generall caused his souldiers to stand and with our

$1 \mathrm{U} 1 \mathrm{~m}$.

2 Vitzthum was the real commander. Possibly Kniphausen was present.

${ }^{3}$ Carretto, Marchese di Grana : it was really Lamboy. 
8000 men made a Ring about them and there our Generall showed f. $55 \mathrm{~b}$. hym the Accord which was made betwixt them, wherein hee had forgotten convoy for his men and mentioned it onely for hymself which was given hym, but his Officers and souldiers were faine to take the kings pay and so lose all his bag and baggage which fell to our horsmen. The Canons and Amunition was sent backe to the Towne and their colours to the Emperour. In the meane tyme the french Army lying so long in this Iland of Gustavus-burg having almost famished them broke up and left the Iland unmanned : but in the Towne of Mentz hee left a thousand Musquetiers and Gallas marching after hym up towards Chritznocke besieged it and in the space of 8 dayes took the Towne in: but the french retreated to the Castle and Gallas leauing went from thence, left 2000 souldiers in the Towne who continually skirmished with those of the Castle, and in the night Coronell Becker, an Ingenious and valourous man got under the shot of the Canon and there entrenched hymself but not without the losse of many a man. The french next morning finding what was donne, sallyed out and besieged this entrenchement and fought the one with the other the space of three howers, but the Imperialists having worked the whole night grew very faint and weary and thorough the greatnesse of the labour were forced to leave the entrenchement, and retreat into the Towne. The french layd the entrenchement levell, a great slaughter there was on both sides, and this continued all the Sommer.

But the Coronell sent to Gallas for 500, Musquetiers who lay betweene Sorbruck and Sweybruck ${ }^{2}$ those forces beeing come hee approached the Castle againe the nights beeing growne longer and f. 56 . entrenched hymself as before, but the french grew weake partly for want of food and men: made one sally more out but with great losse; which discouraged them so that presently they came to a parly and hauing their owne conditions coming out with flying colours etc. were conducted to their Army.

In the meane tyme Gallas marched after the french Army who tooke their retreat towards Metz in Loraine having pillaged the Duke of Sorbrucks" Country with the principall Townes as Sorbruck Sweybruck etc. and following the french over the Moselle sent young Colredo before hym with the Van-gard of 6000 light horse, who meeting with a Troope of french of 200 or thereabout, put them most to the sword, but the principall Officers Kept Prisoners, so going forward marched thorough a Wood, hee saw a party of 2000 french horse which was vpon a Hill with a small Brooke at

1 Saarbrück and $Z$ weibrücken.

- Nassau-Saarbrück. 
the foote but upon the other side of the Hill lay the frenche with his whole Army, Colredo advanced to these 2000 over the Brooke with all his 6000 men, but sent two great Troops to encounter with them and hee marching upon the right hand got to the Top of the Hill, where hee saw the whole Army advancing up the Hill towards hym, but hee slew like a brave souldier most of the 2000 before the rest could come up the Hill. But Coloredo thinking to make a retreat in good order comaunded 3 Coronells with 3000 men who were Binder, Long \& Peter Gets ${ }^{1}$ to hold them in play till hee got over the Brooke and that hee would second them in like case, but his owne souldiers beeing discouraged with that retreat, and the french Army comming on them all fled, and the Ennemy had f. 56 b. the slaughter of them 6 English Miles. Coronell Long was slayne, Coronell Binder and Gets were taken Prisoners. But Coloredo ${ }^{2}$ got away with some 3 or 400 men and came to Gallas who had a great check and was clapt in Prison.

After this Gallas tooke his March into Loraine and some 4 Miles from Metz, the french Card : ${ }^{3}$ meets with hym with the goodlyest sight that ever I beheld with a World of brave horse and men coming up a Hill in such order : and the first day they were clad all in horsemens coats of scarlet colour and sylver lace ; the next day having laid by their coats they were all in bright Armour and great feathers wonderfull beautifull to behold, that wee did looke every day for battaile but striving a long tyme who should begin the round, none would adventure and so at length they both fell to entrench themselves and that very strongly. This was in August where both Armies lay thus facing the one the other for the space of three Moneths togeather but with many skirmishes.

This long continuance in our Trenches made a great famine in Gallas his Army, both of horse and man, that hee lost above twenty thousand men that were famished and did nothing worthy of memory. The Winter coming on ether side retreated but the french rise first, by reason the french could not endure such hardnesse as the Germans: but all their Bravery which they showed at their comming was gonne, wee could see at their parting nether scarlet Coats nor feathers, but sneaked and stole away by little $\&$ by little from their Camp. And it seemes most

${ }^{1}$ Peter Götz, younger brother of the general, Hans Götz.

2 This seems to be a garbled version of the defeat of Colloredo the younger by Gassion in March, I636. Colloredo was captured and imprisoned : not by Gallas however, but at Vincennes.

${ }^{3}$ Cardinal De la Valette. He had with him the flower of the French nobility. Barthold, i, p. 265. 
of their brave horses were eaten or dead for few we could see at their departure nor heare so much neighing of horses as when they f. 57 . came, and that their losse was farre greater then ours in mortality and running away that it was thought, that if with that Army wee had left, our Generall had adventured further into the Country hee had found none to resist hym : and for which hee was suspected to have bene bribed by the Cardinal : and for which hee was mightily checked by the King to have such a brave Army of above 80 thousand strong and to ruine them and doe nothing besides the infinite charge it was to the Empr to which hee answeared as they said that by yt meanes hee kept the french in awe at home that hee could not so well ayde those his Allies abroad in Germany : and the King of Hungary had more leasure to draw in his rebellious subjects and Citties, beeing not well settled after his late Victory at Norling, and further that if hee had hazarded a Battaile and miscarried, all what the King had formerly gotten would have bene presently lost and bene over runne by french. The same they say hee did the next yeare ${ }^{\mathrm{I}}$ after, but I was away here in England : but that hee excused also that hee durst not venture a battaile with the Cardinall for then the Dyet at Ratisbone was in agitation and there was a suspension a while among the Electours about choosing the King of Hongary King of Romans which was so long about that Winter was come on and then it was tyme to goe to Garrison.

Now where wee left; the french beeing retreated into france ; Gallas retreated into Alsatia and tooke in the Towne of Eleschambar $^{2}$ a great Towne upon the passage to Loraine, where lay 15 Companies of french which were convoyed to Metz. And Gallas f. 57 b. went to Landoe in Alsatia and there delt out his Winter-Quarters whither was sent hym a fresh Army of ten thousand Polanders which hee sent to the Entrenchement in Loraine, where hee had layne the whole Sommer with his Army, to keep the frenche in play that hee might ly the quietlier the whole Winter to strengthen his Army against the next Sommer.

Hee sent John de Wert with ten thousand into the Land of Lutzinburg there to have his Winter Quarter: halfe of them hee sent into the Land of Liege ${ }^{3}$ who were all for Hollande \& hated the house of Austria and were the cause that the Hollanders tooke in Mastrick their Country bringing them in provision. John de Wert lying in their Country with his Army did vexe them at heart whereupon the Citty with the Boores grew in rebellion against

1 This must refer to a date late in 1636 . See Introduction.

2 Elsass Zabern.

${ }^{3}$ In the Spring of 1636. 
them and cut of many of his souldiers whereupon hee grew angry and sent for the other 5000 of his Army and wasted their Country, and followed them home even to Lieg and besieged it where hee lay at it the space of 8 weeks with every day many skirmishes but it being very strong by situation and in that tyme hee could not take it, having receaved order from Gallas to ioyne his forces with Picolominie and so to march into france having well wintered his souldiers among their fat Boores hee rise from the Siege and away hee went.

During this Winter Quarter Gallas sent also Count Hatzfield ${ }^{1}$ to ly upon the borders of the Langrave of Hessen his Country with 12 thousand men to bring hym to submission to the Empr all the f. 58. rest of the vnited Princes having submitted themselves (as was afterward seene at the Dyet of Ratisbone) only hee excepted but hee fearing the Emperours Army lying so neare upon his backe, $\&$ his souldiers dispersed into Winter Garrisons writes to the Duke of Saxony to make his Peace with the Empr as hee had donne before for the rest of the Princes and that the Emprs souldiers might not pillage his Country which the Duke obtayned, and none upon paine of death might trouble Coronell Sprighter ${ }^{2}$ his Country who was a Coronell of the Sweues lying nearer where our Army lay. And thinking the peace would bee made betweene the Duke of Hesse and Vs, fell over with 3 Regiments to the Emperour and was maide Sergeant Maior Generall of a flying Army.

But in the meane tyme the Duke of Saxony having need of ayde against Banier the Swevish Generall as I have formerly related in his History, writ to the Emp ${ }^{r}$ to entreat hym that hee would send hym an Army of ten or twelve thousand men; the Empr writ to Gallas to satisfie his request who presently sent the Duke of Saxonie the twelve thousand souldiers who lay upon the Borders of the Duke of Hessen his Country; which beeing donne and got away : so soone as the Duke of Hessen saw hee was rid of his ill neighbours the Emperour's souldiers hee drew his Souldiers out of Garrison ; and made an Army and marched up as farre as Hannow in $\left.{ }^{3} \quad\right]$ which was beleaguered by a part of the Emp ${ }^{r s}$ Army. The Comaunder of Hannow who was old Coronell Ramsey f. $58 \mathrm{~b}$. a Scotch man having gotten notice of the Duke of Hessens coming to succour hym and at hand, and the other side not dreaming of any Adversary nere, sallyed out of the Towne, beat the Imperialists out of their Trenches, having on the other side and hee on the

1 See note 4 on p. 84 .

2 Speerreuter. There is again some confusion in language.

3 A useless lacuna : there is nothing to be supplied. 
other, killed \& drowned in the River of Mume ${ }^{1}$ as good as fower thousand and levelled all their workes.

Duke Hessen victualed the Towne for a yeare and put in fresh souldiers. So soone as the Imperialists heard this presentlv they sent felt Marshall Gots with an Army of 14000 men into the Duke of Hessen his Country againe, and there tooke in one Towne after an other beating his forces at every turne. Hee seeing hymself in this distresse repented hymself of his former foolery, yet having not lost all heart left his chief Towne called Cassell (where hee left his Wife also) as well stored with provision and Souldiers for a siege as his short tyme would give hym leave, and departed bidding her bee of good cheere for hee would leave Malander" his Generall behinde hym who joyning with the Swevish forces who lay in the stift $^{3}$ Breame about the River of Vessure ${ }^{4}$ and hee hymself would ship away presently for Holland and get some new supply of men which joyning with Malander \& the Sweves would quickly relieve her out of that distresse, and whither certainely hee went, for I found hym in Roterdam when I was there in October ${ }^{5}$ last and at Gravesende I met two of his Sonnes comming about some such suites as I thinke to our King leaving his Wife besieged. And since I heare getting some 4 or 5000 Holland forces comming home upon the suddaine with other forces to his have driven the Imperiall souldiers out of the Country.

Now I have gonne as farre as I can of things of any importance f. 59. I am sure, I am sure I have tyred my self if not my Reader. I did not thinke my memory would have carried mee so farre, but one thing draweth on an other which with the help of some od notes I had by mee I have brought to this perfection if any perfection can ly in Warres and bloody histories. And this one thing I may say that what I have here related is true, which few others can doe because those things they publish they have them but at most at second or $3^{\mathrm{d}}$ hand or els from Dutch and lying Corantoes: ${ }^{6}$ and withall I doe not take upon mee to goe any further then in those things which were of importance and wherein I my self was an Actour, where were of those 3 greatest set

1 Main. The word is almost illegible.

3 Peter von Holzapfel; called also Melander.

3 Stift Bremen as before, p. 47.

4 Weser.

5 Barthold, i, p. 364. But this is certainly October, 1636 and proves that Poyntz could not have written till very late in 1636 or early in 1637 . See the Introduction.

6 "Courants." "Newsletters" of the time. 
Battailes that were fought in Christendome these hundred yeares, I meane betweene Christian and Christian and all within the compasse of a yeare $\&$ half and had such valourous Leaders that they were fought to the very last man as you may read and that which showes the Battailes were fought to the last for those that [had] taken many Prisoners were glad to let them goe againe to save themselves. And I call these Battailes of Importance for if the Emp ${ }^{r}$ had fayled \& bene overthrowne in ether of these two last Battailes, viz. in that wherein the King of Sweve was slayne or in the last of Nerling, the Empr and his issue and the house of Austria would quickly have bene put besides his Crowne, but God it seemes defended \& vpheld hym miraculously, and in my opinion in nothing more then in Wallestons conspiracy, which the more private it was, the more dangerous.

f. 59 b. And now a little to myself, how often have I seene fortunes, and first I will begin with those of higher rancke, for when I began first as many others did to follow after Mansfield like mad folkes wee knew not whither I came into Germany with other troopes of souldiers wee passed thorough many brave Princes Countries in all which wee had supply of Men and Money and where wee found such plenty of all things for backe and belly that heart could desire and had got pretty store of Crownes : but at the length wee had a Crosse of fortune, for Tilly met with us \& stript us naked of all Canon, Amunition and whatsoever wee had, yea with the death of most but those that saved their lives by running away: yet at length our Army was encreased againe by those Protestant Princes thorough whose plentifull Countries wee had marched; that at that tyme when we met $w^{\text {th }}$ Bethlem Gabor wee were got to 30 thousand which also as I told you before came to nothing, and worse then nothing by the death of Mansfield and Weymar, and most of many brave souldiers fell into miserable captivity where wee were stript of all that wee lightly got in that long journy, but lost in an hower, and made slavish Slaves $\&$ nightly chayned by the feet to a great $\log$ after our sharpe dayes Labour, which was so terrible to fellowes of brave spirits that they did strive to dy $\&$ could not, and that which grieved mee as much as for my self was for a brave young gentleman of a Duke of Barlamonts house ${ }^{1}$ in Italy, and wee called hym Count Barlamont, who was beaten to death before our faces, because his Spirit was so great as would not yield to bee a drudge. But now to my self I saw there was no striving tooke upon mee an humble spirit and fell to my drudgery

1 The Duke of Barlamont was really a Walloon nobleman. 
hoping once for a light night as they say and went merrily to my Worke and strove to get the language and now \& then some money by hooke or by crooke $\&$ hid it in od corners : so after 2 or 3 yeares patience, opportunity fell that I got away and some f. $60 \mathrm{~b}$. 40 myles but was brought backe with a vengeance and had 300 blowes on my feet which cooled my running for one yeare. But God at length did prosper my intentions, for I got a brave horse which at length brought mee to the skirts of Christendome, but fortune threw mee againe on my backe, met with theeves got all my little Mony and horse and all : O how that went to my heart to part with my horse, which had brought mee out of the Devills Mouth, and so neare Christendome, I meane Austria, where hee would have given mee a hundred pound if some other had had hym, but no remedy. After all these Crosses the Sunne began to shyne clearly upon mee as I have formerly showed you how luckily I light upon a poore franciscan an English-man by name A. More, and somewhat allyed by marriage to our name in Sussex. Then I rise by fortunes from a Lieutenant to a Capt ${ }^{\mathrm{n}}$ of a troop of Horse in Saxons Armie, but beeing taken Prisoner by the Imperialists I lost againe all that I had under the Saxon Duke. Thus fortıne tossed mee up and downe, but I sped better then I expected; for I was taken Prisoner by Count Butler with whome after I got in favour hee raysed mee extreamely: for by his favour hee got mee my first Wife, a rich Merchants Daughter, who though wee lived not two yeares togeather, shee dying in child-bed to my great grief, yet shee left mee rich, and she was of an humble condition and very houswifly, wee should have lived very happily togeather; and if shee had lived but halfe a yeare longer I had come to greater Wealth : for within that tyme after her death, her father \& Mother, who lived in Aegre where I got my wife, dyed, f. $60 \mathrm{~b}$. and left a World of Wealth which came to strangers, having no child nor childs child; and not content with this the good Count Butler got mee an other Wife, rich in Land and mony, but of a higher birth \& spirit, and therefore would live at a higher rate than our meanes would well afford, for no Lady in this Land wore better close than she did, besides her Coach and 6 Coach-horses $\mathrm{w}^{\mathrm{ch}}$ with Attendants answearable to it would bee very expensive and had great Kindred that lay vpon vs. But I beeing come to this height got to bee by Count Butlers favour Sergeant Maior of a Troop of 200 horse but I was to raise them at my owne charge, which was no small matter for mee to doe, beeing so well underlayd and so well aforehand, for I had then $3000 £$ which I carried into the field with mee besides that I left at home with my Wife, 
and besides that I had layd out about some land I bought which lay nere my ${ }^{1}$ Wives Lande. And I made good use of my place for I could and did send home often tymes Mony to my Wife, who it seemes spent at home what I got abroad, but fortune turned against mee againe for in that cruell bloody Battaille where in the King of Sweveland was killed, my horses were all ether killed or ranne away : for that night after the Battayle (when Walleston was glad to withdraw out of the field) our Camp beeing at rest horse and man, an Officer came from our Generall to every Officer to know what strength every company was of. One came to mee I beeing in a dead sleep and my horse as weary as I lying on the ground by mee asleep, to know the like of mee, but after great f. 60 . adoe to wake mee, I could give hym but account of 3 Officers of my Companie which lay there downe by my side. It seemes hee found most of his Companies as weake as myne, for presently that night the Army was comaunded to march away without sound of Drum or Trumpet, and so wee marched 8 Miles that night before wee refreshed ourselves againe : but the march was so suddaine, that every one that had baggage, horse and Wagons were glad to leave his baggage behinde hym, for our horses were all strayd and run away beeing played upon continually by the Swevish Canon though they stood a Mile of. For Walleston to make his Army seeme bigger, had together all the Women, struggers and boys of the Camp with horses and wagon-Jades to stand togeather to make as it were a great Troop with sheets for their flags, who when they saw the Canon shoot so fast upon them, run all away; though souldiers were sent to keep them togeather, where I lost most of my wealth, and could bring no more away then I and my 3 weary Officers could carry; and Walleston was in the same predicament hymself for hee was faine to leave all his canon and baggage behinde.

At the beginning great store of prisoners were taken on both sides, I my self was taken prisoner three tymes but twice I was rescued by my fellowes; the third tyme beeing taken hold of by my belt, having my sword in my hand, I threw the belt over my Eares and rescued myself. I lost three horses that day beeing shot under mee, and I hurt under my right side and in my thigh, but I had horses without maisters enough to choose and horse my self; all had pistols at their saddle bowe but shot of and all that I could

1 This was clearly in Würtemberg. This second wife is the lady mentioned by Aubrey (Surrey, IV, 2I2, 2I3) under the curious title 'Anne Eleonora de Court Stephanus de Cary in W rtemberg,' and we may refer all the events alluded to to the time of Butler's command at Schorndorf in 1635 . The Story of Litzen is with Poyntz's habitual disregard of chronology, put after this second marriage. 
doe, was with my sword without a scabard, and a daring ${ }^{1}$ Pistol but no powder nor shot: my last horse that was shot had almost f. $61 \mathrm{~b}$. killed mee for beeing shot in the guts, as I thinke, hee mounted on a suddaine such a height, yea I thinke on my conscience two yards, and suddaine fell to the ground upon his bum, and with his suddaine fall thrust my bum a foot into the ground and fell upon mee and there lay groveling upon mee, that hee put mee out of my senses. I knew not how I was, but at length coming to $\bar{m}$ yself, with much a doe got up, and found 2 or 3 brave horses stand fighting togeather. I tooke the best, but when I came to mount hym I was so bruised \& with the weight of my heavy Armour that I could not get my leg into the saddle that my horse run away with mee in that posture half in my saddle and half out, and so run with mee till he met with Picolominie comming running with a Troop of horse und my horse run among them that I scaped very narrowly of beeing throwne cleane of but at length got into my saddle full of paine and could hardly sit, and followed the Troop having nothing but a daring Pistol and a naked Sword.

No more Prisoners taken that day, every one strove to save hymself. Here fortune left mee almost bare againe, and well she left mee at so bloody a battaile with life. But this losse I did prittily well recover that Winter beeing billeted in Austria among rich Boores, by hooke or by crooke, I got mee strong in horse and men as I thought any had; but it fell out so that with continuall marching this spring from one side of Germany to the other, to help the miserly Duke of Saxon against the Sweve: and from thence backe againe to Loraine from whence wee went at first to Gallas who lay there entrenched with the Army, and the famine wee endured so long there, my Troop grew so short $\&$ poore $\&$ the Country growne so f. 62 . poore that nothing was to bee got amongst the Boores upon whome alwais lay the Comaunders hopes whilest they were in good plight, for wee might bee our own carvers, for we had no other pay : these failing, my thoughts were in despaire of ever raising my companie againe: And I had almost $2000 £$ in my purse with mee at that tyme, yet I considered it would goe hard to part with my ready Money, and nothing to bee got, and I knew not how things stood at home, and to goe empty handed home would not doe so well, considering also I had left a costly Wife at home : and having bene almost a whole yeare in Warres, I set up my rest of going home, and mee thought a private life after these wandring wearisome marches did relish sweetly in my thoughts and so after a long march I came nere home, where I heare the true tryall of fortunes

1 ? Swaggering : really ineffectual, but making a brave show. 
mutability, which was that my Wife was killed \& my child, my house burned and my goods all pillaged : My Tenants and Neighbours all served in the same sauce, the whole Village beeing burned; nether horse, Cowe, sheep nor Corne left to feed a Mouse, This when I came home I found too true some poore people got into the ruines living with roots: this went nere mee. This was donne by a party of french that came out of Italy going homewards : here was little comfort for mee to stay here : then I presently determined to go see my deare friend Count Buttler Governour of that Country, who lived some two or 3 Leagues ${ }^{1}$ from thence at the [ the head Citty of the Dukedome of Michelburg, but my hopes were turned upside downe, for it was my good hap to see hym, but he was dying, which strucke more nere to mee, or as much as my

f. 62 b. owne losse, but there was no remedy, but yet it somewhat revived hym and what show of love a dying man can expresse, hee did grasping my hand with all his strength and calling for his Will gave mee a thousand pound therein and not long after having receaved his Viaticum with a great sylver Crucifix in his hand and in my Armes yielded up the Ghost. I had thought my heart would have burst with grief, but could get out no teares out of my stony heart : but to my owne heart I cryed Spes et Fortuna Valete, my hopes and fortune now farewell, who if hee had lived, I had had fortune almost at my becke; but hee beeing dead about the $1000 \delta$ hee gave mee his Wife beeing his Executrix and not so friendly to mee as she might have bene, and her husbands love to me required, kept mee so of with delayes, and at last I was forced to goe to Ratisbone where the Emp ${ }^{r}$ was expected about it, but never the nearer, and there also I was as nere but the charge in expecting was so great as the debt it self would not countervaile it and finding there an English Embassadour ${ }^{3}$ made as much use of his favour as I could in my passe hither, away I went for England loosing my frend and his guift.

But it is by the way worthy your consideration and myne which I did observe more of fortunes mutability whilest I was at Ratisbone in others cases then myne owne had donne, and it made a great impression in mee : for when I wandred out of my owne Country, I knew not whither, and I followed I knew not whome, wee went, I well remember, thorough many brave Dukes and Princes Countries

1 This fixes the position of Poyntz's estates in the neighbourhood of Schorndorf.

2 Again a lacuna without meaning. Butler died at Schorndorf. Michelburg (= Mecklenburg throughout) must be Würtemberg.

${ }^{3}$ John Taylor, cf. State Papers : Domestic : $1635^{-6}$, passim. 
of Germany full of all things that belonged to mans vse and of all things wee had supplies of men and mony as wee passed : for mee that had seene the one now to come to see the contrary was wonderfull, viz. their Countries destroyed, their Townes burned, f. 63 . their people killed and most of themselves or by their Embassadours making their Peace with the Emp ${ }^{r}$ while I was there and some that I had knowne formerly in the Warres: Captaines and Lieutenants, there I met with, who of themselves falling into passionate Exclamations against the late king of Sweveland and his officers cursing the tyme of his comming who had brought them to blood and beggery, the pretense of whose comming was to deliver them from the tyrannies of the $E \mathrm{mp} \mathrm{p}^{\mathrm{r}}$ threw them into an other farre worse; having carried most of the Treasure out of Germany into their owne Country and left them in worse plight at the Emp $\mathrm{p}^{\mathrm{rs}}$ mercy then at first by farre and that which troubled these Captaines and officers most was the pride of the King of Swevelands officers especially Oxenstall whome the King made Chancelour of Germany and his place of residence should bee [ $\left.{ }^{1}\right]$ where all the revenews which should come to the maintenance of the Kings warres in Germany, and there bee kept and distributed as necessity required. And the Towne to be called the Chancery or Exchecquer of Germany, but little went out to the souldiers or Officers, though with Warrant from the King, for Oxenstall would still complaine of want of Money in the Exchecquer unlesse they would take Land in such a Dukedome or such which had bene newly gotten and easily, all flying from the face of the Conquerour as from a Lyon, and withall his pride was so great that they might have a dispatch twice from the King before from hym once and bee they Dukes or whosoever or of what ranke soever they must attend many dayes and two or 3 roomes of before they were admitted. This drew an infinite hate of them.

But to myself I posted to England to see how fortune had dealt f. $36 \mathrm{~b}$. with mee for my estate there, whither when I came, to adde more vexation and grief I found our house extirpated \& sold out of the name, the land and revenew in like sort dispersed and severed to many buyers, which if my wild \& wandring head had had any braynes or consideration as one of 16 or 17 yeares of age might have had and so kept in England, it might have bene the cause it had not come to ruine as it hath donne or at least so soone.

And if I had not bene reasonably well underlayd, I meane with Money at my coming out of Germany which journy was very

${ }^{1}$ Augsburg according to Poyntz himself (p. 57 supra). 
chargeable to mee, I might have begged, for any friendship of my owne kindred, and I must confesse I found great friendship from those that were mere strangers to mee which was Sir L. Tresham and his Lady, in whose house I have writ these my poore labours and for whose sake I reduced them to this head, and seeing my expectation had failed mee here and no employment in England in that faculty of souldiery, which I have followed from my youth, I doe give a Longum Vale to my Country, and a Longum Vive to my Soveraigne Lord \& King, King Charles and will try my fortune againe where I first raised it, and where I left a great deale of dead-Land which, if it please God, a happy peace to bee betweene the Empr \& his subiects I may come to such an Estate there as may beseeme a greater man then myself. But yet so farre am I bound to fortune (if there bee any such a thing as fortune but divine providence) it hath delivered mee from servitude, kept mee since like a gentleman and in good respect with greater persons

f. 64. then my self and at last left mee in an other manner of Estate then when I first departed from my native Country. And so here is an End of the Peregrination of 